\title{
COMPARATIVE STUDY ON COAGULABILITY OF FISH MUSCLE PROTEIN*
}

\author{
Usio Srmidu** and Wataru Simidu*** \\ Received June 18, 1960
}

The results described in the previous paper(1)(2), show the clear differences among various species of fish in the rate of protein denaturation during frozen storage. This fact, coupled with wide taxonomical range in fish leads us to expect that there might be possible differences in the nature of their muscle protein. Actually, such differences were generally accepted in the field of manufacturing fisheries products.

We have as yet few comparative studies on the fish muscle proteins. Electrophoretic studies of fish proteins revealed some differences existing among extracts of low ionic strength as well as high ionic strength of salt solutions of muscle from - various species of $\mathrm{fish}^{(3-5)}$, but the biochemical or practical meanings of the results are yet obscure. Shimizu and Shimidu ${ }^{(6)}$ determined the composition of the protein fractions on several species of fish and observed no clear difference in relative composition of actomyosin fraction (extractable in $0.6 \mathrm{M} \mathrm{NaCl}$ solution) and the myogen fraction (extractable in $0.1 \mathrm{M} \mathrm{NaCl}$ solution) among these fishes.

In this study, some attempts have been made to reveal the difference among the muscle proteins of the several species by comparing the salt extractability and the heat coagulability of muscle proteins.

\section{Heat coagulation of muscle solution}

Fine sliced muscle from fish was ground in a large mortar. $100 \mathrm{~g}$. of the ground muscle was treated with $1,000 \mathrm{ml}$ of $0.6 \mathrm{M} \mathrm{NaCl}$ solution and extracted 2 hours with occasional stirring, After filtering through cotton cloth, each $20 \mathrm{ml}$ of the solution was put into a test tube and heated in a water bath at various temperature for 5 minutes then cooled by water. The solution was centrifuged and nitrogen content was determined by the Kjeldahl method on portions of the supernatant.

Fig. 1 shows the heat coagulation curves obtained from some species of fish. The fish used consisted of mackerel (Scomber japonicus Houtruys) weighing $205 \mathrm{~g}$., and yellowtail (Seriola quinqueradiata Temminck et SchlegeL) of average weight $655 \mathrm{~g}$. They were supplied for testing about 10 hours after their catch. In case of yellowtail, materials were stored at $-15^{\circ} \mathrm{C}$. for certain periods, and the frozen muscle was sliced without pre-thawing, and macerated in salt solution as above. Thawing of muscle took place during the grinding.

* 昭和 34 年 4 月 3 日日本水産学会にて請演; 京都大学審査学位諭文の一部

** The Institute of Food Microbiology, Chiba University

*** Department of Fisheries, Kyoto University 


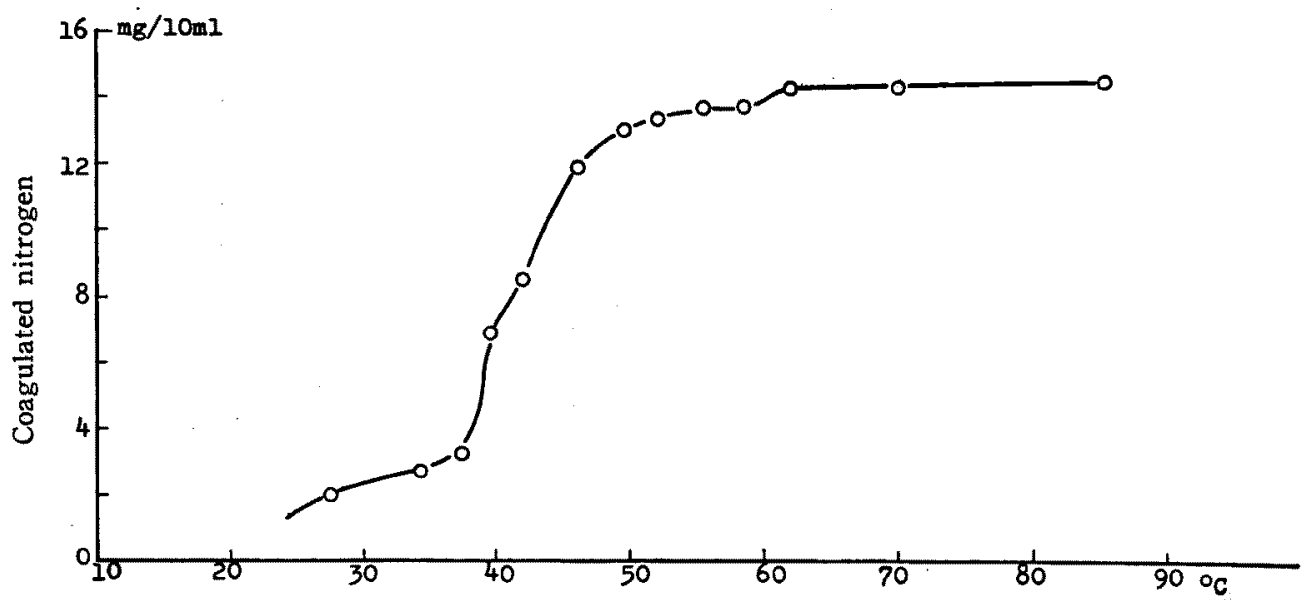

Fig. 1-A.

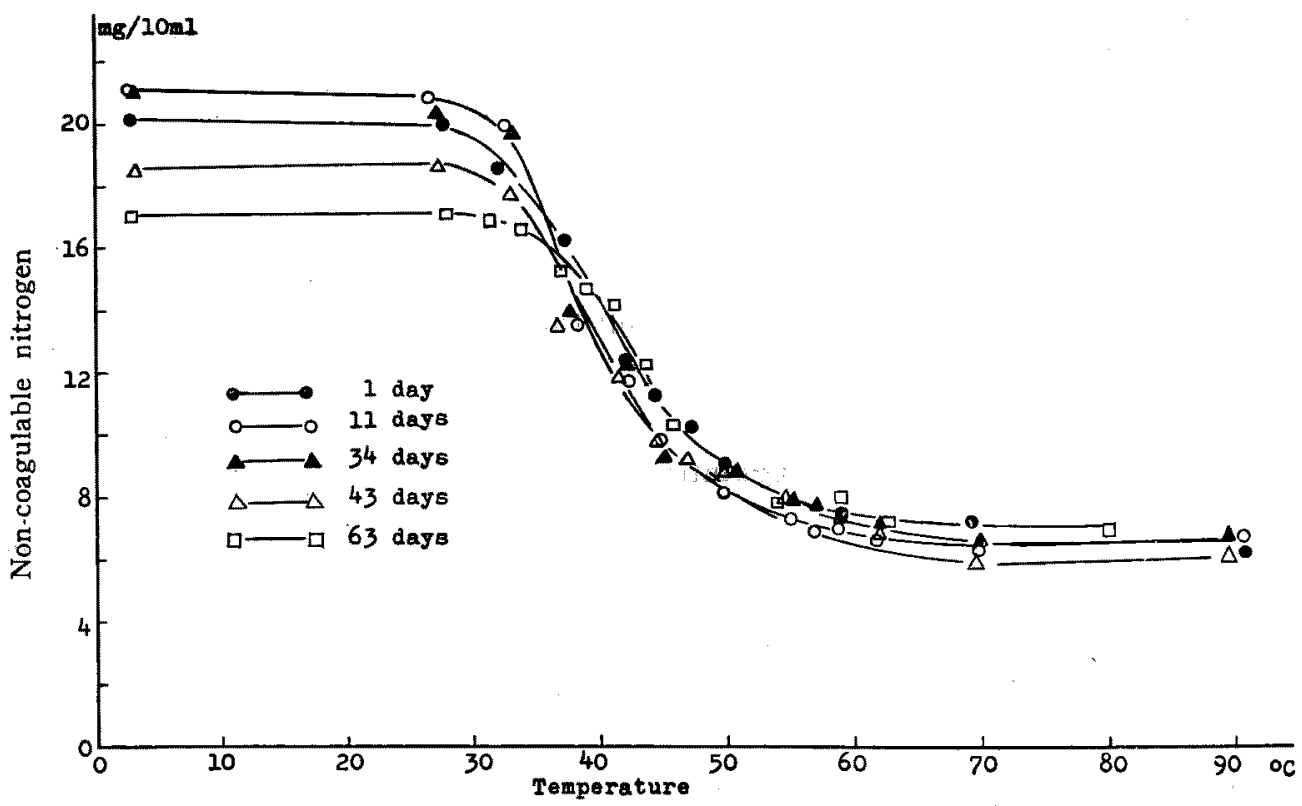

Fig. 1-B.

Fig. I. Heat coagulation of muscle protein from a mackerel (Fig. 1-A), and from yellow tails stored at $-15^{\circ} \mathrm{C}$. (Fig. 1-B).

From Fig. 1 it is seen that most of muscle proteins precipitate between $35^{\circ}$ and $55^{\circ} \mathrm{C}$. Little change in the curves of heat coagulability was observed after frozen storage.

An entirely different result was obtained in the case of lizard-fish (Saurida elongata (Teminck et Schleger)). The fish averaging $275 \mathrm{~g}$. were devided into two lots and stored at $-15^{\circ} \mathrm{C}$. and at $+5^{\circ} \mathrm{C}$. respectively. At intervals, they were tested as above. At a temperature of $30^{\circ} \mathrm{C}$, muscle solution from this fish formed a homogeneous 
viscous sol, and at $45^{\circ} \mathrm{C}$., a small amount of granular precipitate appeared. Though the suspension became turbid, no appreciable amount of precipitate could be obtained by the centrifugation at 4,000 r.p.m.

When the muscle was suspended in $2.2 \mathrm{M} \mathrm{NaCl}$ solution and heated, a bulk of elastic gel-like clots which adhered to a glass rod was formed at a temperature of $45^{\circ} \mathrm{C}$. Although a quantitative experiment was not performed, the solution tended to flocculate as the concentration of the muscle was increased.

In stored lizard-fish (Fig. 2), the muscle suspensions showed a tendency to flocculate at $45^{\circ} \mathrm{C}$ to $55^{\circ} \mathrm{C}$., but at higher temperatures the solution became homogeneous and gave little or no precipitate by centrifugation.

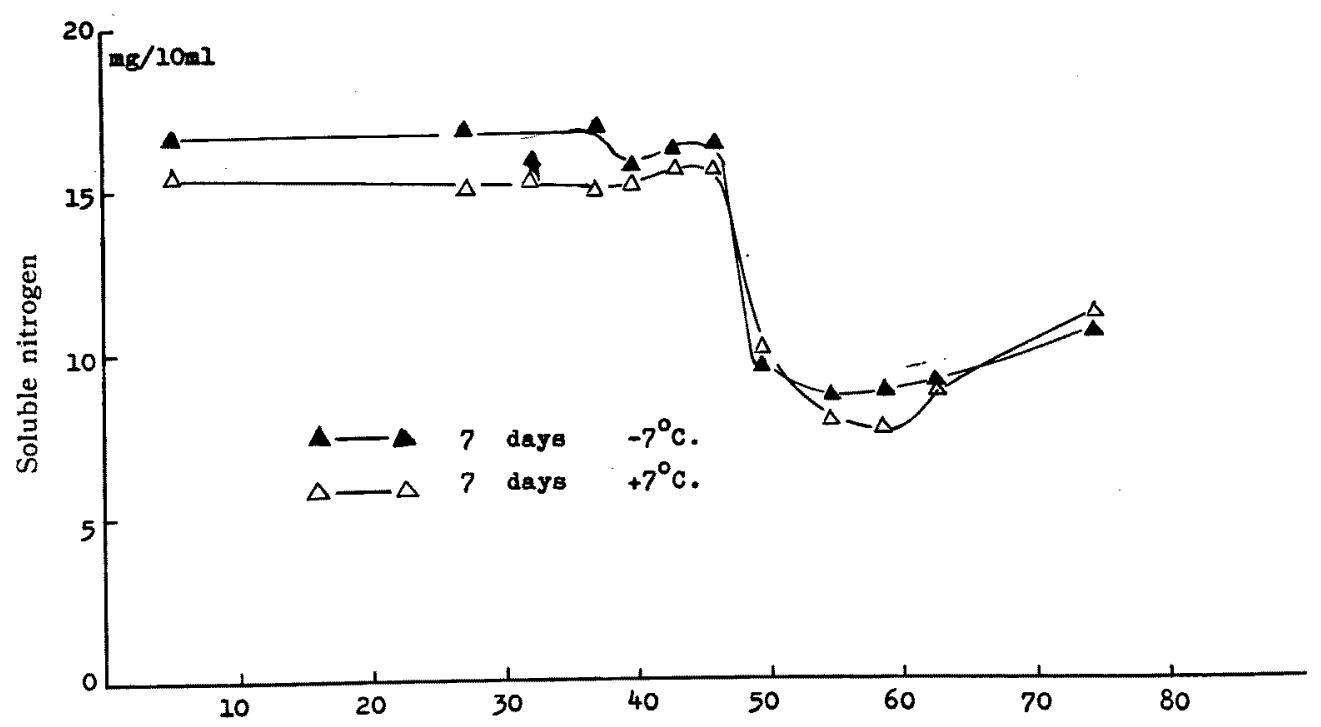

Fig. 2. Heat coagulation of muscle protein from stored lizard-fish.

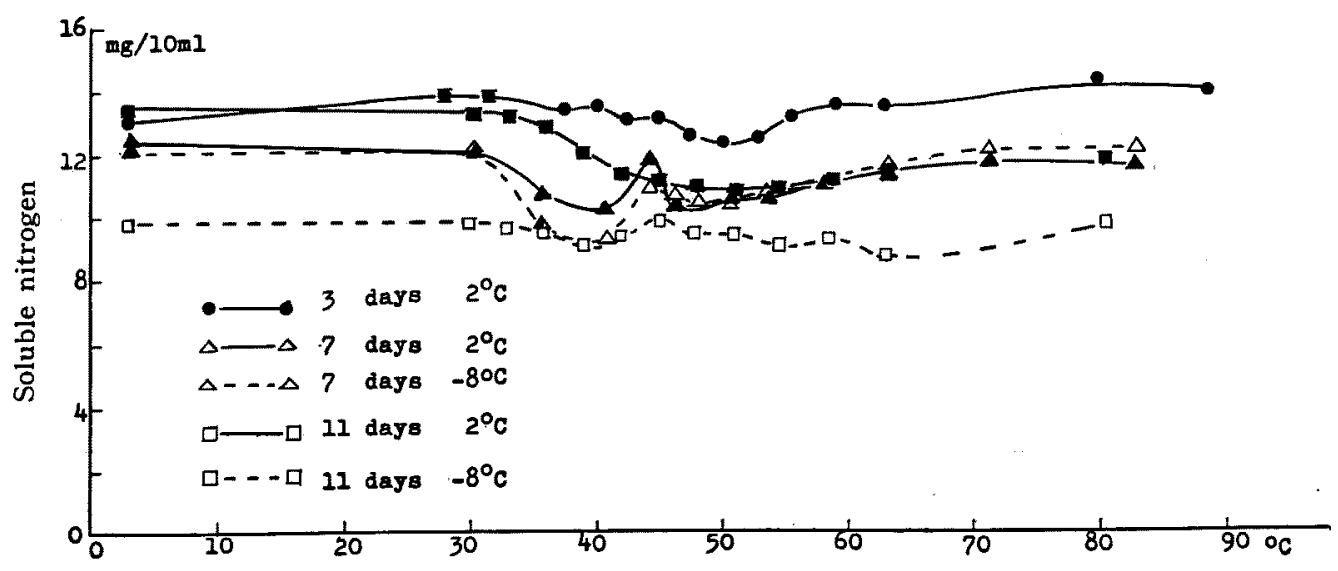

Fig. 3. Heat coagulation of muscle protein from stored lizard-fish (fine homogenized muscle suspension). 
The method of grinding muscle mentioned above was unsatisfactory for preparing a fine homogeneous muscle suspension. When the muscle was homogenized in a Waring Blendor (Homogenizer) with an equal quantity of water and then dissolved in $0.6 \mathrm{M} \mathrm{NaCl}$ solution, the muscle solution of lizard-fish showed more resistance to separation by centrifugation as will be seen in Fig. 3.

\section{Relations among extractability, heat coagulability and $\mathrm{pH}$}

It has been shown that the solubility of actomyosin depends upon salt and hydro. gen ion concentration ${ }^{(7)}$. Dyer et al. ${ }^{(8)}$, using cod muscle, showed that the amount of extractable protein in salt solution of $\mu=0.85$ increased sharply between $\mathrm{pH} 5.5$ and 6 .

The differences in heat coagulability of fishes might be explained by the effect of $\mathrm{pH}$, since muscle from the red muscle fishes such as mackerel and yellowtail is known to show the marked decrease in $\mathrm{pH}$ value in post mortem period, often to the extent of $\mathrm{pH} 5.4^{(9)}$.

In order to determine the effect of $\mathrm{pH}$ on both extractability and heat coagulability, the following experiment was performed. The muscle was homogenized with an equal quantity of $0.1 \mathrm{M} \mathrm{NaCl}$ solution using the Waring Blendor. To $50 \mathrm{~g}$. of the muscle mush, $500 \mathrm{ml}$ of $0.6 \mathrm{M} \mathrm{NaCl}$ solution was added and stirred. Each $40 \mathrm{ml}$ of the muscle solution was put into a small conical flask and the $\mathrm{pH}$ value of the solutions were adjusted by adding $0.5 \mathrm{M} \mathrm{HCl}$ and $0.5 \mathrm{M} \mathrm{Na}_{2} \mathrm{CO}_{3}$ solution. After 3 hours' extraction, 10 $\mathrm{ml}$ of the solution were centrifuged, while the other $10 \mathrm{ml}$ of the solution were

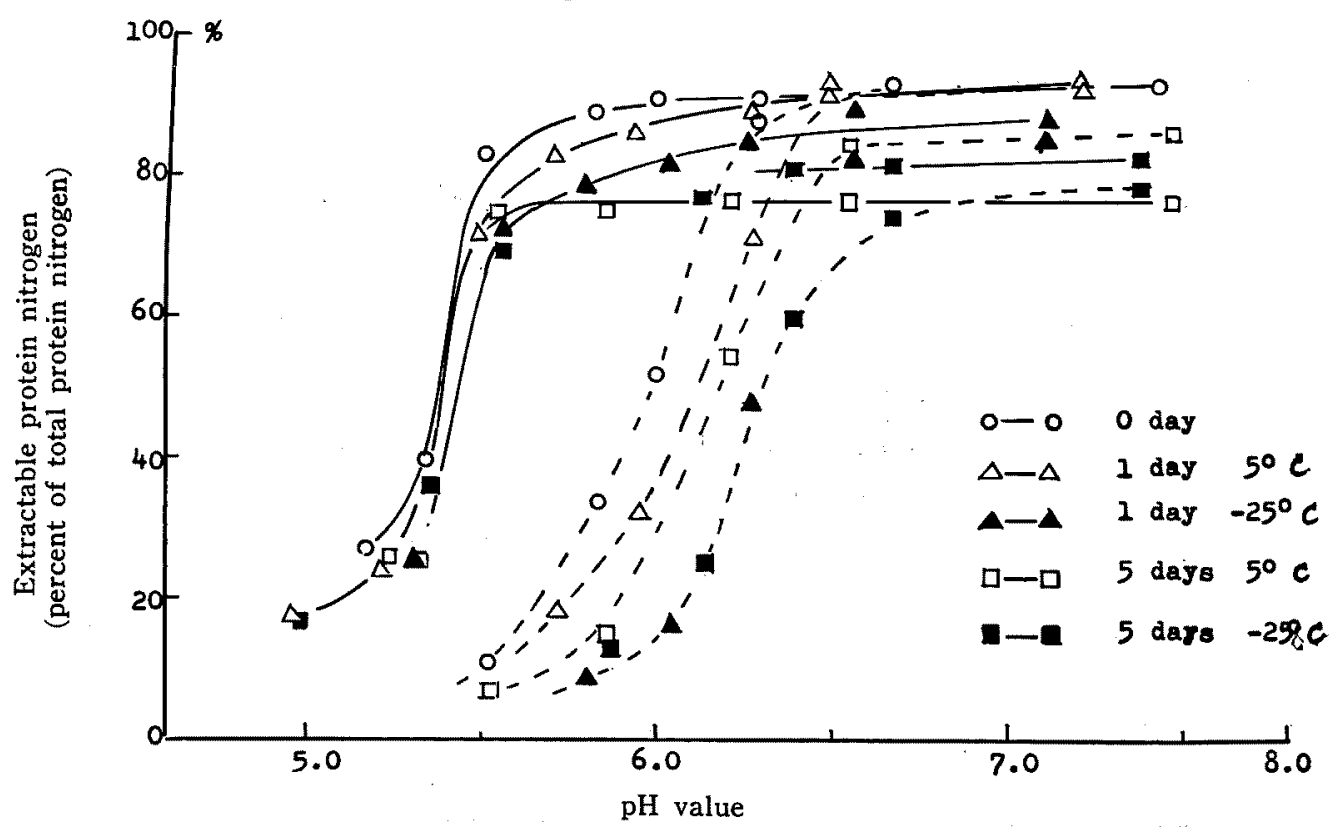

Fig. 4. Relation among extractability, heat coagulability and $\mathrm{pH}$ of muscle solution from horse mackerel. Solid line: Extractability before heating. Dotted line: Extractability after heating. 
heated in a boiling water bath for 5 minutes at $100^{\circ} \mathrm{C}$. and also centrifuged after cooling. The content of protein nitrogen was determined by the biuret method in an aliquot of the supernatant in both heated and non-heated solutions. The $\mathrm{pH}$ values of the solution were determined after 3 hours' extraction by means of a Shimidzu pH meter using a glass electrode.

The results obtained from the experiment on horse mackerel (Trachurus japonicus (Temminck et Schlegel)) are shown in Fig. 4. Material used consisted of fish with weights ranging from 12 to $38 \mathrm{~g}$. and averaging $26 \mathrm{~g}$. They had been caught in the summer by angling and were used for the experiment immediately after killing or after storage at $5^{\circ} \mathrm{C}$. and $-25^{\circ} \mathrm{C}$. for a certain period.

From Fig. 4, it is clear that after only 1 day's storage, especially frozen storage, a considerable change was produced in heat coagulability; the $\mathrm{pH}$ range in which most of the proteins precipitated was raised. In the untreated intact fish muscle, such changes will be distinctly emphasized, since the $\mathrm{pH}$ of muscle decreases in the earlier period of storage.

The results from similar experiments on some other species of fish are shown in Fig. 5. These results show that there are no marked differences in the effect of $\mathrm{pH}$ on the protein extractability among the species of fish investigated. These results are essentially in agreement with that of Hamoir (5) who showed that the curve did not depend on the species of fish.

In contrast to the extractability, the heat coagulability of these protein solutions varies considerably. Muscle solutions of mackerel and yellowtail coagulated at a $\mathrm{pH}$ of 6.6 or higher, but those of lizard-fish and croaker (Pseudosciaena manchurica



Fig. 5. Relation among extractability, heat coagulability and $\mathrm{pH}$ of muscle solution from mackerel (Fig. 5-A), from yellowtail (Fig. 5-B), from lizard-fish (Fig. 5-C) and from croaker (Fig. 5-D). 


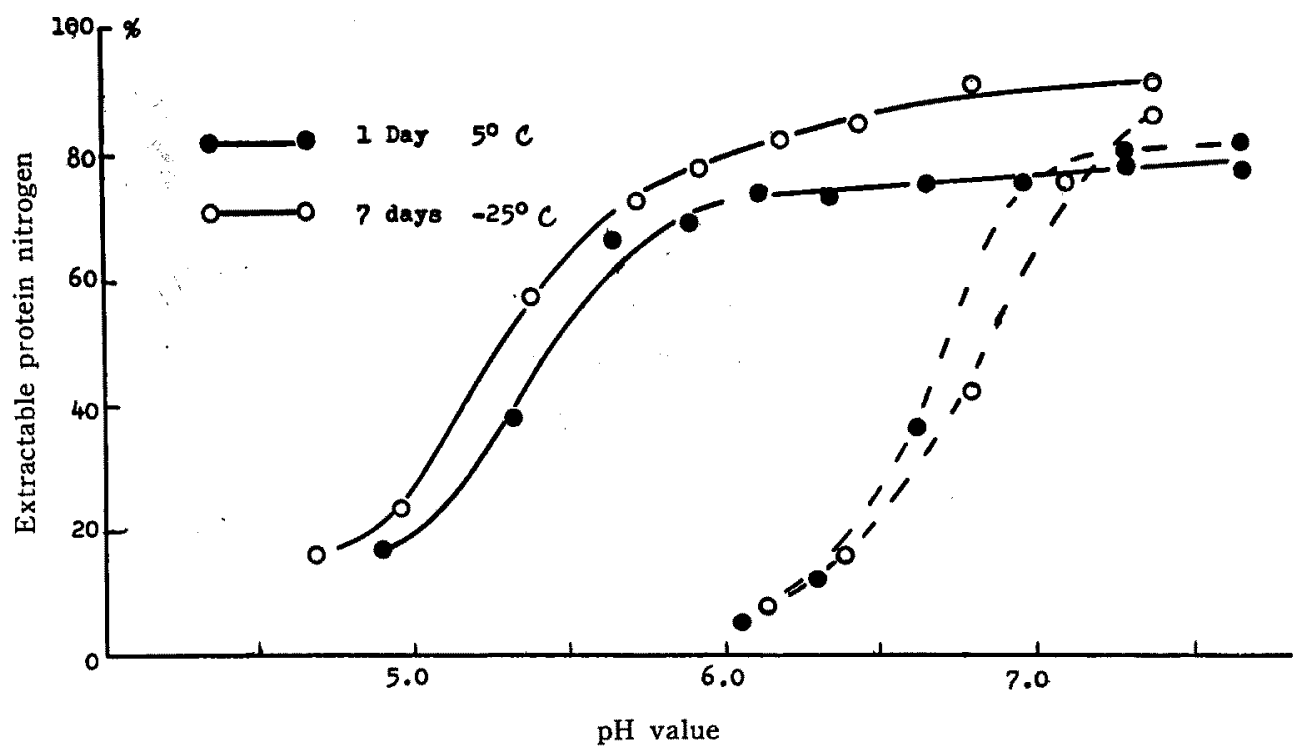

Fig. 5-B

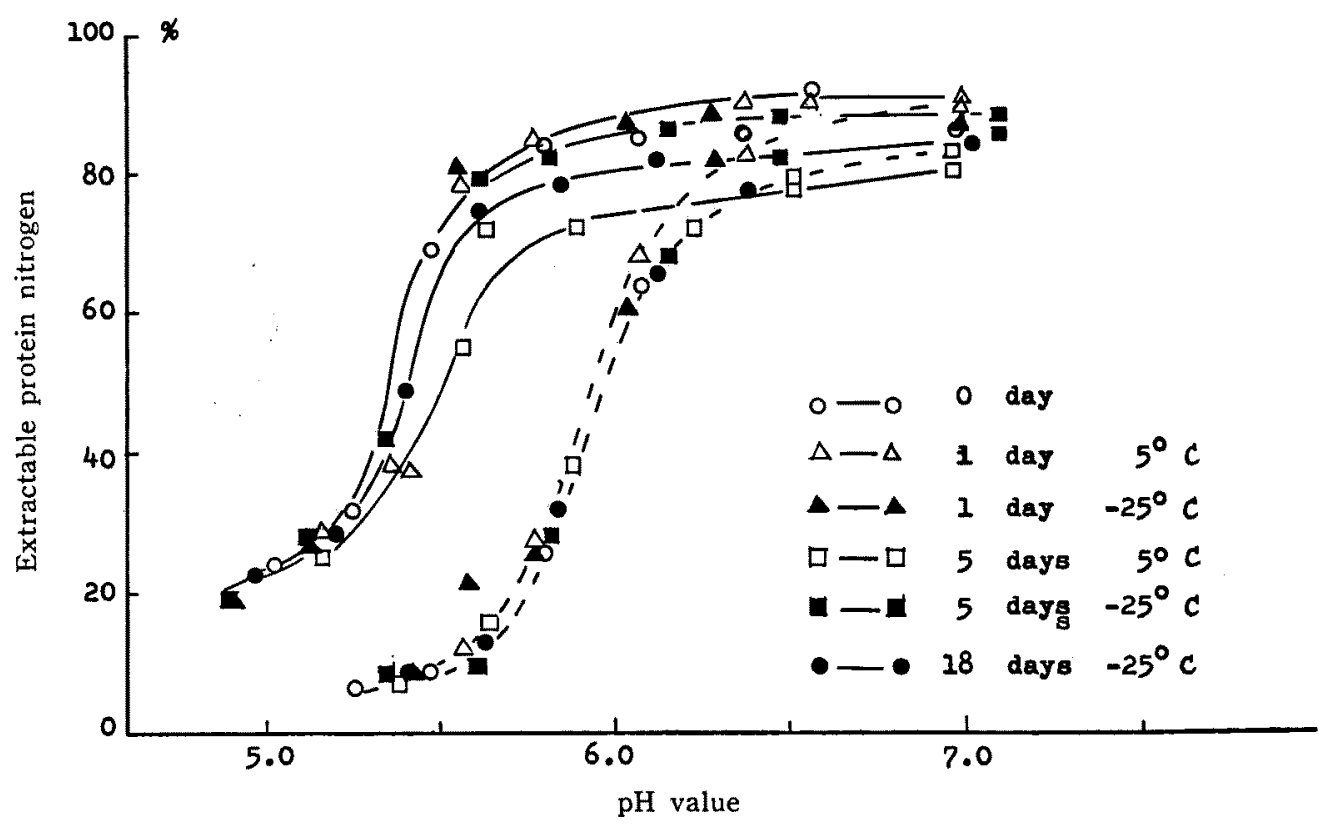

Fig. 5-C

(Jordan et Thompson)) failed to coagulate at a $\mathrm{pH}$ as low as 6.0. Horse mackerel coagulated at a $\mathrm{pH}$ lower than mackerel and higher than croaker and lizard-fish. It is of interest that the $\mathrm{pH}$ value required for coagulation varies with the darkness of muscle color and the briskness of motility of these fish. 


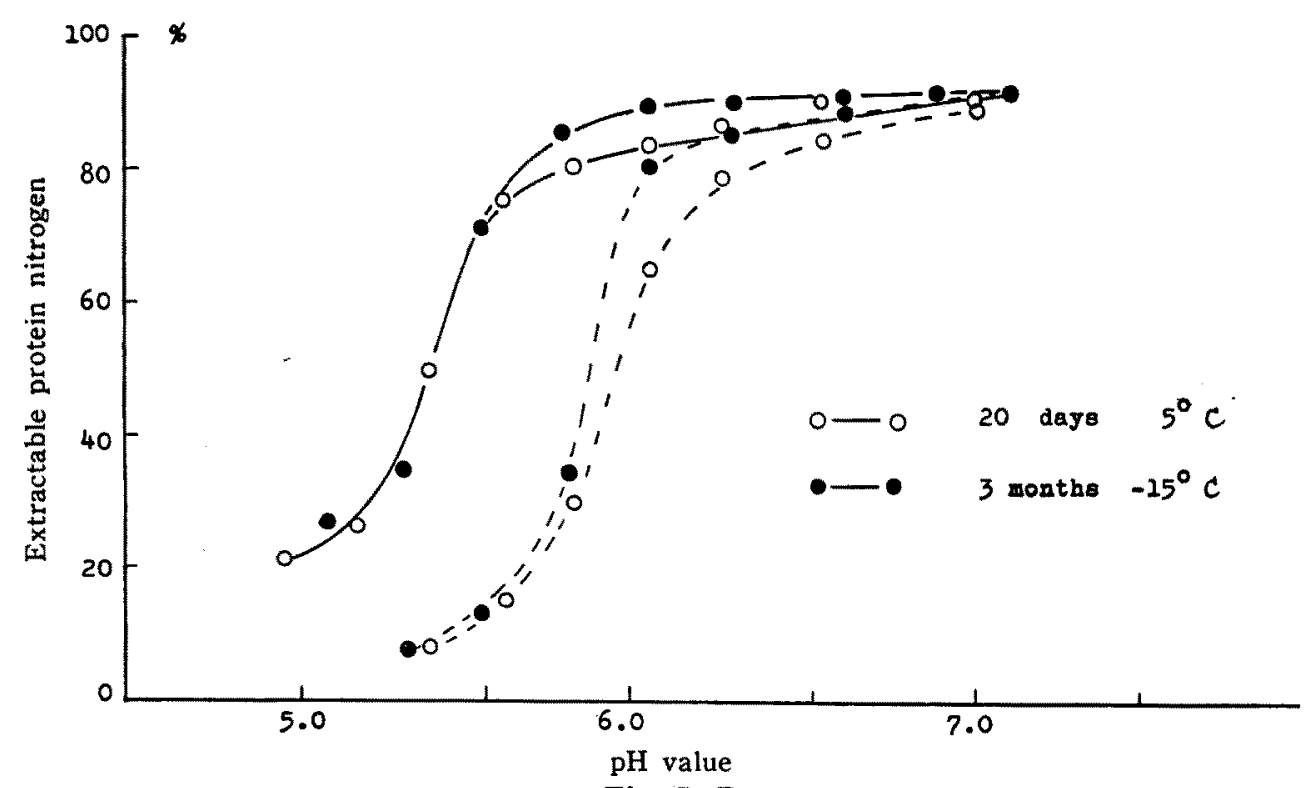

Fig. 5-D

\section{Discussion}

It seems of significance that the muscle solutions from lizard-fish or croaker, which give a good and uniform product in making the fish cakes or Kamabokos, coagulatein a lower $\mathrm{pH}$ range when heated and do not coagulate at the $\mathrm{pH}$ range of their fresh muscle. On the other hand, the muscle solution of mackerel and yellowtail which are generally not fitted for such products coagulate at higher $\mathrm{pH}$ than their muscle of post mortem period. These fish also do not give a good salted or dried fish products, unless they are in very fresh condition. The fish such as horse mackerel can give good materials for the fish cakes as well as other products if they are fresh. The fact seems to correspond to the experimental results: the muscle solution from fresh horse mackerel coagulated at rather higher $\mathrm{pH}$ value and, varying with the lapse of storage time, the $\mathrm{pH}$ value causing the coagulation decreased.

It is believed that the formation of clear, stable gels of muscle or muscle solution is the most essential factor responsible for the good quality of some kinds of the fisheries products such as dried, salt-cured, and smoked fish, as well as fish cakes and fish sausages. On the other hand, the coagulation or aggregation of protein during processing the products, resulting in the crumbling of the protein gels, causes the products to soften or become turbid and lose elasticity.

It was known that denatured protein gels can be formed only under highly specific conditions $^{(10)}$. Simidu et al. ${ }^{(11-12)}$ studied several kinds of fish for the condition in which fish muscle made a rigid gel when heated. However, the cause of the different abilities to form the rigid gels among fish were not fully interpreted. 
In the present experiments, the clear differences among the heat coagulability was revealed. It seems probable that the formation of gel or homogeneous sol in heating muscle solution is correlated with the formation of rigid, clear gel of fish proteins in processing products.

It seems possible that the gel formation, showing water holding capacity of protein molecules, depends on the nature and amounts of the ions existing in muscle. The present investigation was carried out on the whole fish muscle, but not on the actomyosin isolated. The differences observed among various species may be due to the differences in amount of ions existing in muscle, or most probably the decrease in $\mathrm{pH}$ in muscle of the red muscle fish may result in some irreversible change in properties of muscle protein so that the water holding capacity of the protein is lost.

\section{References}

1) Simidu, W. \& Simidu, U.: Bull. Jap. Soc. Sci. Fish., 23, 442 (1957).

2) Simidu, W., Simidu, U. \& Terasima, H.: Bull. Jap. Soc. Sci. Fish., 23, 701 (1958).

3) CONNELL, J. J.: Biochem. J., 54, 119 (1953).

4) Dingle, J. R., Eagles, D. E. \& Neelin, J. M.: J. Fish. Res. Bd. Can., 12, 75 (1955).

5) HaMoIR, G.: Arch. intern. physiol. et biochem., 63, suppl. (1955).

6) Simidu, Y. \& Simidu, W.: Unpublished.

7) Hamolr, G.: Advances in Protein Chem., 10, 227 (1955).

8) Dyer, W. J., French, H. V. \& Snow, J. M.: J. Fish. Res. Bd. Can., 7, 585 (1950).

9) Noguchi, E.: Bull. Japan Sea Reg. Fisheries Res. Lab. Fisheries Ayen;. B5 (1957).

10) FERrY, J. D.: Advances in Protein Chem., 4, 1 (1948).

11) Shimidu, Y., Simidu, W. \& Ikeuchi, T.: Bull. Jap. Soc. Sici. Fish., 20, 209 (1954).

12) Shimidu, Y., Simidu, W. \& Ikeuchi, T.: Bull. Jap. Soc. Sci. Fish., 20, 295 (1954). 